\title{
Assessment of entrepreneurial and intrapreneurial orientation constructs: An analysis of past research
}

\author{
Chris Schachtebeck \\ Darelle Groenewald \\ Cecile Nieuwenhuizen \\ University of Johannesburg, South Africa
}

\section{Keywords}

Intrapreneurial orientation, entrepreneurial orientation, corporate entrepreneurship

\begin{abstract}
Entrepreneurial Orientation (EO) can act as a predictor and indicator of firm-level entrepreneurship in organisations of different sizes. Intrapreneurial Orientation (IO), as an offspring of EO, describes an individual employee's inclination to act entrepreneurially. Yet while the importance of an organisation's EO cannot be overstated, a lack of clarity exists as to which common constructs underpin these concepts, as no study has attempted to analyse the shared conceptual basis underpinning EO, IO and other connected concepts. The purpose of this study is to analyse the underlying constructs of past EO and IO studies. The study is qualitative in nature by utilising a narrative review methodology. The review was conducted in prominent international databases. Discovered articles were analysed by means of content and thematic analysis. Results reveal that EO studies mostly utilise three constructs, namely risk-taking, innovativeness and proactiveness, while competitive aggressiveness and autonomy are less frequently utilised. Instruments developed by Miller (1983), as well as Covin and Slevin (1989) were the most frequently utilised instruments to assess EO. Studies investigating IO lack commonality in constructs, with only innovativeness representing a common construct. Entrepreneurial Attitude Orientation was found to act as an extension to $I O$, utilising similar constructs and one underlying instrument only. Findings of this study provide researchers and academics with an up-to-date identification and analysis of the main constructs underlying popular EO and IO instruments, thereby assisting in the development of instruments in future EO and IO studies.
\end{abstract}

Corresponding author: Chris Schachtebeck

Email addresses for corresponding author: cschachtebeck@uj.ac.za

First submission received: $17^{\text {th }}$ February 2018

Revised submission received: $3^{\text {rd }}$ April 2018

Accepted: 22nd May 2018

\section{Introduction}

Entrepreneurship is generally believed and validated to be associated with risk-taking, innovation and crafting of a competitive advantage (Kuratko, 2017; van Aardt \& Bezuidenhoudt, 2017). Miller (1983) laid the foundation in determining the traits of an entrepreneurial organisation and thereby allowing industry and academia alike to distinguish between entrepreneurial and non-entrepreneurial ventures. Yet, in many organisations the fundamental factors promoting entrepreneurial actions are not present, such as an absence of innovation, a lack of competencies, low levels of managerial skills, poor marketing and lack of financial support (Dyer \& Ross, 2008; Farsi \& Toghraee, 2014). To drive entrepreneurial actions within organisations, Entrepreneurial Orientation (EO) emerged as a predictor and driver of internal organisational performance (Covin \& Slevin, 1991; Wiklund, 1999). The adoption of EO has been shown to positively influence organisational performance (Rauch, Wiklund, Lumpkin \& Frese, 2009), particularly in the areas of proactiveness, innovativeness and autonomy (Matchaba-Hove \& Goliath, 2016). The emergence of $\mathrm{EO}$ has further resulted in a significant volume of research investigating $\mathrm{EO}$ from a conceptual point of view, thereby prompting the development of a cumulative body of knowledge (Rauch, et al, 2009).

Paradoxically, while there exist generally acknowledged common constructs of EO, few empirical studies actually utilise all five dimensions of EO, namely innovativeness, risk-taking, proactiveness, 
autonomy and competitive aggressiveness (Covin \& Lumpkin, 2011). While the EO concept is therefore multidimensional in nature, the constructs are often approached as a unidimensional construct (Junior, Borini, Bernardes \& de Oliveira, 2016). Therefore, there seems to exist an uncertainty around what it truly means for an organisation to be 'entrepreneurial' (Anderson, Kreiser, Kuratko, Hornsby \& Eshima, 2015). While the EO concept and its underlying constructs have received significant attention in academic literature, a number of prominent scholars are postulating differing constructs, antecedents and motivations for EO (Covin \& Wales, 2012). The purpose of this article is to review studies which have empirically utilised EO and IO and proceed to assess the underlying constructs. The study therefore sums up a volume of research over a period of time and analyses the utilised EO and IO constructs.

\section{Problem statement}

While the EO concept has been in existence for a number of years, IO has only recently evolved out of the EO concept. As IO is born out of EO concept, the fundamental conceptual purpose is similar, yet pitched at an individual level, rather than at an organisational level. With this in mind, a number of authors (Wang \& Altinay, 2010; Jain \& Ali, 2013; Sinha \& Srivastaa, 2013; Filser \& Eggers, 2014; Kantur, 2016; Nobile \& Husson, 2016) have utilised EO and IO to characterise organisational entrepreneurial behaviours and stance. The utilised EO and IO constructs commonly include some shared constructs, such as risk-taking, innovativeness and proactiveness, as proposed by Miller (1983). As EO and IO are both evolving bodies of knowledge, it emerged that confusion still exists around commonality in underlying constructs, which vary from study to study and contain both behavioural and attitudinal components. This means that, while Miller's (1983) definition of EO is regarded as the foundation of EO/IO research, additional constructs have been introduced, as well as established constructs amended. These additional constructs have not been mapped in recent literature in terms of commonality of use. It is therefore arduous to establish which emerging constructs are utilised in practice and whether Miller's (1983) constructs are still used in their original form in modern $\mathrm{EO} / \mathrm{IO}$ research.

\section{Objectives}

Primary Objective

The primary objective of the research is to determine the underlying constructs and antecedents past studies have utilised when investigating Entrepreneurial and Intrapreneurial Orientation.

Secondary Objectives

- To ascertain the existing range of EO and IO research

- To describe existing prominent $\mathrm{EO} / \mathrm{IO}$ constructs and antecedents

- To map EO and IO research trends

\section{Literature Review}

The following sections present a literary discussion of prominent literature on the constructs, antecedents and research trends behind the topics of Entrepreneurial Orientation and Intrapreneurial Orientation. A theoretical and conceptual overview of each topic presented.

\section{Intrapreneurial Behavior}

While Intrapreneurship has its roots in entrepreneurship theory and was formally defined by Pinchot in the 1980s (Pinchot, 1985), Macrae (1982) first alluded to the emergence of a novel entrepreneurial dynamic, whereby organisations effectively compete with themselves. Macrae (1982) stated that "the methods of operation in business are going to change radically in the next few decades, in a direction opposite to that which most businessmen and nearly all politicians expect". The act of 'intrapreneuring' (Pinchot, 1985) can be described as intrapreneurial behaviour within an existing organisation (Antoncic, 2007). From an individual employee's perspective, intrapreneurship can, attitudinally, be regarded as an individual employee's willingness to actively search for new opportunities with the intention to pursue these opportunities creatively (Morris, 2001). It is therefore that Robinson, Stimpson, Huefner and Hunt (1991) developed the Entrepreneurial Attitude Orientation (EAO) scale to more accurately gauge the attitudinal component of an individual employee's EO, rather than from a firm-level perspective that traditionally characterises EO. Burgers and Van Der Vrande (2016) argue that since an employee's entrepreneurial actions are not part of their job function, the employee is 
required to possess an intrinsic entrepreneurial motivation or receive stimulation by means of a supportive organisational environment.

While the term 'intrapreneurship' was coined in the 1980's already, a number of differing concepts and terms exist which embody the intrapreneurship concept and actions. These terms include "intra-corporate entrepreneurship, corporate venturing, internal corporate entrepreneurship and firmlevel entrepreneurial posture" (Antoncic \& Hisrich, 2004). Taştan and Güçel (2014:863) describe intrapreneurship as "an entrepreneurial way of action in an existing organization" and indicate that intrapreneurship positively contributes towards an organisation's profitability motive, innovation capability, strategic posture and potential future revenue streams. While these benefits can be attributed to effective implementation of intrapreneurship, conceptually intrapreneurship can pursue differing objectives. Intrapreneurship can be implemented with the aim of establishing a new venture, or alternatively to achieve strategic renewal by refocusing internal strategic efforts (Guth \& Ginsberg, 1990). However, both aims result in an enhanced entrepreneurial process, culminating in improved levels of innovation, or corporate renewal (Guth \& Ginsberg, 1990; de Villiers-Scheepers, 2012).

\section{Entrepreneurial Orientation}

Entrepreneurial Orientation is often referred to as a strategy-making process that aims to provide an underpinning for entrepreneurial decisions and actions in organisations (Lumpkin \& Dess, 1996). In particular, EO "represents the policies and practices that provide a basis for entrepreneurial decisions and actions" (Rauch et al., 2009:6) and can be summarised in terms of how new entry is undertaken (Lumpkin \& Dess, 1996). Hughes, Ucbasaran and Lewis (2016) term EO the 'mindset' of the organisation as it acts as a motivator to act creatively, innovate, develop an opportunity-seeking mindset and tolerate risks in return for reward. As EO has its roots in organisational strategy development, it is most closely associated with competitive actions at an organisational level that are aimed at improving competitive standing and entrepreneurial actions (Rauch et al., 2009). Entrepreneurial Orientation is therefore also regarded as an organisation's "strategic posture towards entrepreneurship" (Anderson et al., 2015:1579), which Khandwalla (1997) merely describes as strategic options. Rauch et al. (2009) explain that a number of measurement scales for EO have been developed and their influence on other variables is being examined. However, Rauch et al. (2009) elaborate that EO is a developing field that warrants further research.

Miller (1983) originally conceptualised three underlying dimensions of EO, namely innovativeness, proactiveness and risk-taking. Lumpkin and Dess (1996) add the dimensions of autonomy and competitive aggressiveness to Miller's (1983) framework. The authors however note that the five underlying dimensions can vary independently depending on organisational, environmental or individual context. Innovativeness refers to an individual's predisposition to act in a creative manner and, in an organisational setting, develop new products and processes. Proactiveness refers to the adoption of an opportunity-seeking mindset, most commonly with the aim of introducing innovations to the marketplace before competitors, thereby creating a first-mover advantage. Risk-taking refers to the ability to tolerate ambiguity and demonstrate a willingness to suffer potential losses in the pursuit of new opportunities. Autonomy can be described as the individual employee's ability to work in a self-directed manner. Competitive aggressiveness refers to an organisation challenging existing competitors in the marketplace, whether directly or indirectly, by means of new products, process, activities or other offerings (Lumpkin \& Dess, 1996; Jacobs \& Kruger, 2001). Wiklund and Shepherd (2005), in a review of prominent EO studies, suggest that EO tends to be primarily comprised of three dimensions, namely innovativeness, proactiveness and risk-taking. These three dimensions have to be viewed contextually as these dimensions vary based on context, however some authors found that the dimensions co-vary as a grouping (Covin \& Slevin, 1989; Jain \& Ali, 2012).

Covin and Slevin (1991) suggest that entrepreneurial behaviours in organisations need to be sustained over a period of time for an organisation to be considered entrepreneurial. Entrepreneurial behaviours therefore require sustained effort and consistent behavioural patterns, rather than a one-off entrepreneurial effort that is regarded as a blip in time. Anderson et al. (2015:1582) cite Miller (2011) and Covin and Lumpkin (2011), by stating that confusion still exists "whether EO is fundamentally a behavioural phenomenon or whether it represents some kind of attitudinal, philosophical, or dispositional characteristic among strategic decision makers". This can be attributed to the underlying constructs 
containing both attitudinal and behavioural characteristics. While an attitude can be regarded as a precursor to a behaviour, it cannot be assumed that both share similar antecedents, particularly in EO research (Anderson et al., 2015).

\section{Intrapreneurial Orientation}

While EO makes reference to the organisation-wide strategic stance on entrepreneurial actions, IO concerns itself with the entrepreneurial ambitions of the individual employee (Bolton \& Lane, 2012). The individual entrepreneurial traits of employees can be regarded as important, if not more so, than the stance of the organisation and its leaders (Sinha \& Srivastava, 2016). Intrapreneurs hold significant value for organisations as intrapreneurship holds the ability to identify opportunities, determine resource requirements and manage new ventures (Hisrich \& Peters, 2002), in a manner which deviates from past practices and allows the organisation to fulfil its strategic goals (Heinonen, 1999) in an innovative manner (Fasnacht, 2009). In addition, in the context of an innovative organisation, IO can be regarded as paramount as employees will be an integral component of the internal innovation process (Manimala, Jose \& Thomas, 2006). The challenge of determining an IO is that no single or combination of personality traits, individual characteristics or attitudes can predict entrepreneurial behaviour as these factors are contextbound. These context-bound factors, in combination with individual learning, can be regarded as IO (Jain \& Ali, 2012).

Yet Robinson et al. (1991) argue that EO has some attitudinal components to it that will predict an individual employee's future entrepreneurial behaviours. The Entrepreneurial Attitude Orientation (EAO) scale therefore acts as an extension to $\mathrm{EO}$ by investigating attitudinal components of entrepreneurship in individual employees, thereby encroaching on the IO domain. Wunderer (2001:194) describes this phenomenon as 'co-intrapreneurship' by stating that "co-intrapreneurial orientation unites a responsibility for the whole and, at the same time, enables teams to practice their own local flexibility and freedom". Other authors term the IO phenomenon as 'Intrapreneurship Attitude Orientation', which ultimately results in innovative pursuits by employees, with the assistance of a supportive leader (Sinha \& Srivastava, 2016). This indicates that intrapreneurship does not merely flow from the top of an organisation, as EO theory dictates, but is practiced by each individual employee.

The importance of the orientation of each individual employee is such that "without an EO to guide them, employees in an organization are unlikely to combine and use knowledge in novel ways, which can result in myopia" (Hughes, Ucbasaran \& Lewis, 2016:98). Khandwalla (1977) stated that some authors therefore suggest that where a strong internal entrepreneurial orientation exists, it is fitting to find an organic orientation, due to the existing internal risk-taking stance and associated resource commitments. IO tends to be underpinned by five key dimensions (Lumpkin \& Dess 1996:136): proactiveness - preparation or intervention for an expected situation; risk-taking - behaviour that can result in losses or failure; competitive aggressiveness - a tendency to proactively challenge competitors in a marketplace; innovativeness - the introduction of a new or different product, service or process; and autonomy - the search for independence, discretion and freedom from control. While IO is believed to be underpinned by the outlined five key dimensions, other prominent studies have found a correlation between only three factors and $\mathrm{IO}$, namely proactiveness, innovation and risk-taking propensity (Antoncic \& Hisrich, 2003; Lumpkin \& Dess, 2005; Aarakit, 2010).

\section{Research Methodology}

This study utilised a descriptive research approach by means of employing a qualitative narrative review. Hunter and Schmidt (2004) explain that a narrative review is literary and qualitative in nature and non-quantitative. It therefore differs from other review methods, such as scoping or systematic reviews, which primarily aim to either determine the mere extent of research conducted or synthesise and assess research findings quantitatively (Grant \& Booth, 2009). The purpose of a narrative review is to take the results of each study to "find an overarching theory that reconciles the findings" (Hunter \& Schmidt, 2004:445). A narrative review can serve the purpose of synthesising evidence in an effort to describe underlying processes and conceptual models (Milat, Bauman \& Redman, 2015). The study aims to discover and describe the underlying constructs and antecedents of entrepreneurial orientation at an organisational level, as well as an intrapreneurial orientation at an individual level. 
The review involved targeted internet keyword searches in prominent electronic databases, including Ebscohost, Emerald, Springerlink, Sabinet and Sage. A number of keywords were utilised in the search, which included 'entrepreneurial orientation', 'intrapreneurial orientation' and 'entrepreneurial attitude orientation'. While alternative keywords such as 'Individual Entrepreneurial Orientation' could have been included, the selected keywords best capture the investigated phenomenon. The narrative review included full-length journal articles, in the form of empirical studies resulting in frameworks and conceptual models. Articles which were only available as abstracts were excluded from further analysis as the underlying constructs could not be reliably analysed. Further, studies which were not empirical in nature, such as conceptual papers or reviews, were excluded from analysis. The review was conducted in June 2017. To be included in the study, articles had to meet the following criteria: be i) published in English; ii) available in full-length, iii) outline underlying constructs utilised in the study; iv) focus on determining EO or IO; v) empirical in nature. Data analysis took the form of thematic and content analysis. Each underlying construct in the identified study was coded as part of the content analysis, with patterns and trends then being discovered by means of thematic analysis. As significantly more research on EO has been conducted, the results may capture the EO concept more comprehensively.

\section{Findings}

The initial literature search for the three outlined concepts yielded a total of 322 discovered studies. Of the 322 studies, 146 were discarded as they were either not available as full-text, did not focus on investigating EO, IO or EAO, or were not empirical in nature. Of the remaining 176 articles, 36 were duplicates and were hence discarded. The remaining 140 articles were analysed in terms of the underlying constructs and instruments being utilised to measure EO, IO and EAO. The breakdown for each concept and database is provided in Table 1.

\begin{tabular}{|c|c|c|c|c|}
\hline Concept & Database & Discovered & $\begin{array}{c}\text { Not } \\
\text { Accepted } \\
\text { for } \\
\text { Analysis }\end{array}$ & $\begin{array}{l}\text { Accepted } \\
\text { for } \\
\text { Analysis }\end{array}$ \\
\hline \multirow{5}{*}{$\begin{array}{l}\text { Intrapreneurial } \\
\text { Orientation }\end{array}$} & Sabinet & 6 & 1 & 5 \\
\hline & Ebscohost & 3 & 1 & 2 \\
\hline & Emerald & 5 & 4 & 1 \\
\hline & Sage & 4 & 1 & 3 \\
\hline & Sub-total & 18 & 7 & 11 \\
\hline \multirow{5}{*}{$\begin{array}{l}\text { Entrepreneurial } \\
\text { Attitude } \\
\text { Orientation }\end{array}$} & Sabinet & 13 & 4 & 9 \\
\hline & Ebscohost & 12 & 6 & 6 \\
\hline & Emerald & 12 & 10 & 2 \\
\hline & Sage & 13 & 12 & 1 \\
\hline & Sub-total & 50 & 32 & 18 \\
\hline \multirow{5}{*}{$\begin{array}{l}\text { Entrepreneurial } \\
\text { Orientation }\end{array}$} & Sabinet & 34 & 13 & 21 \\
\hline & Ebscohost & 74 & 44 & 30 \\
\hline & Emerald & 94 & 30 & 64 \\
\hline & Sage & 52 & 20 & 32 \\
\hline & Sub-total & 254 & 107 & 147 \\
\hline \multicolumn{2}{|c|}{ Totals (All Concepts) } & 322 & 146 & 176 \\
\hline \multicolumn{4}{|c|}{ Less Duplicates } & 36 \\
\hline \multicolumn{4}{|l|}{ Net Total } & 140 \\
\hline
\end{tabular}

Table 1 Preliminary results of literature search

Source: Author's compilation

Figure 1 shows the constructs utilised in the discovered studies. The diagram depicts commonalities in constructs between EO, IO and EAO. The size of each 'bubble' depicts the extent to which each construct appeared in the analysed studies. Figure 1 indicates that overlap exists between EO, IO and EAO. IO shares constructs with the EO concept, which is to be expected as IO can be regarded as born out of EO. On the other hand, EAO can be seen as an attitudinal extension to IO, and shares some 
constructs with IO, such as Achievement Orientation, locus of control, perceived personal control, selfesteem and the work environment. The work environment construct is however also determined by the components of the 'management' construct. An indirect relationship therefore seems to exist between the 'management' aspect of IO and the nature of the work environment. The size of the bubbles in Figure 1 indicate that proactiveness, innovativeness and risk-taking are important components in both EO and IO, with competitive aggressiveness and autonomy emerging as shared, yet less frequently utilised constructs. The three 'original' constructs of EO, as proposed by Miller (1983) therefore emerge as dominant themes for the EO concept. The following sections will discuss the findings from the perspective of EO, IO and EAO.

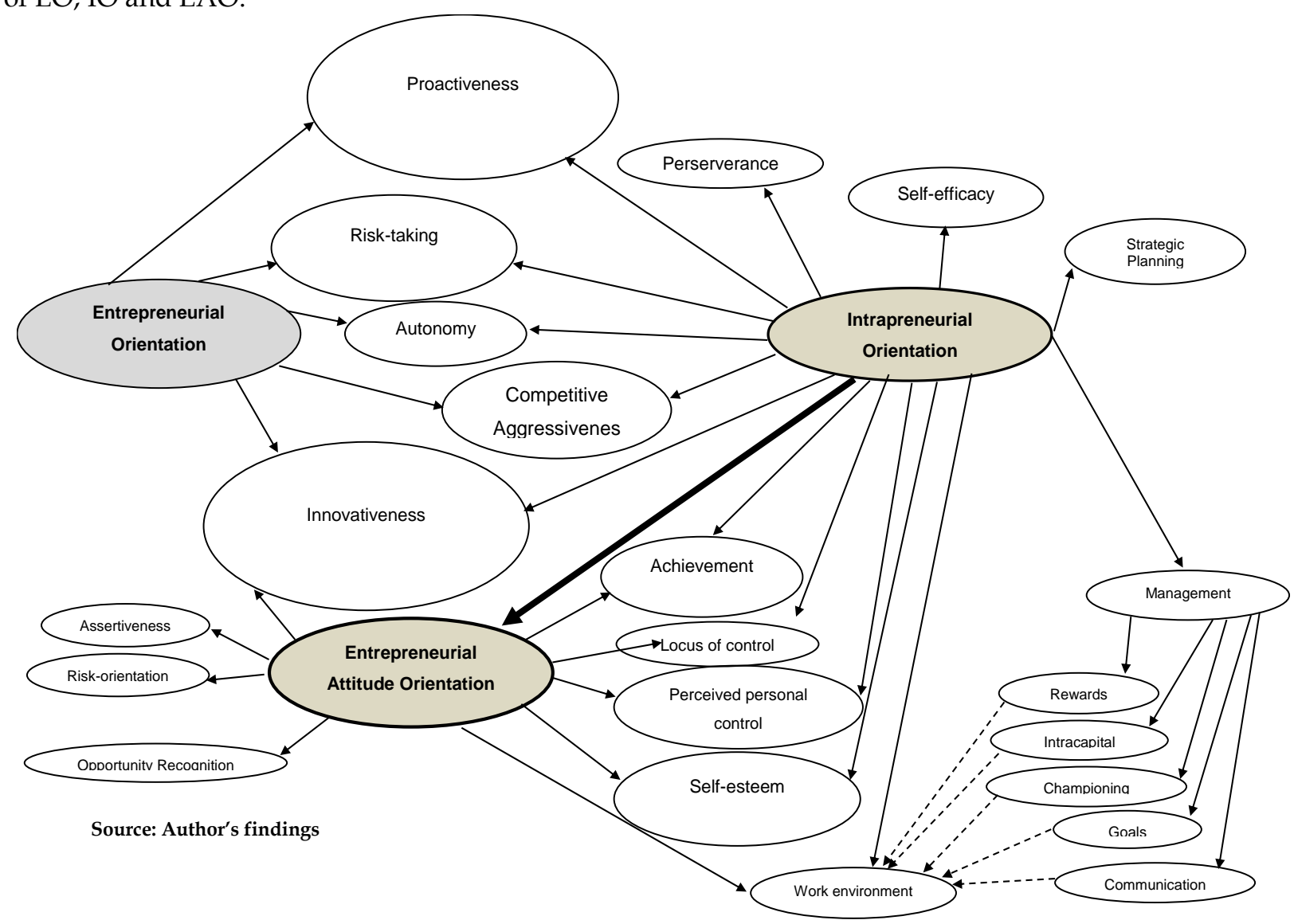

Figure 1 Construct Map

\section{Entrepreneurial Orientation}

The bulk of all discovered studies relate to the EO concept (82.5\%). A large proportion of studies (approx. 80\%) utilised a small range of underlying instruments and constructs that were adapted for each specific use. The instruments were primarily based on instruments originally developed by Miller and Friesen (1982), Miller (1983), Covin and Slevin (1989) and Lumpkin and Dess (1996). This is consistent with findings seen in other reviews, such as by Wales (2016). Six studies utilised self-developed instruments and did not make reference to the aforementioned authors, yet these contained similar elements to the prominent, existing instruments. It is however noteworthy that the abovementioned instruments are mainly rooted in the three-item scale developed by Miller (1983), as well as a questionnaire by Khandwalla (1977). The findings for EO concur with other studies which suggest that EO contains primarily three elements, termed the one-dimensional approach, namely innovativeness, risktaking and proactiveness. The findings for the EO concept are therefore similar to the conclusion drawn by Wales, Gupta and Mousa (2011), who highlight in their systematic review the pervasiveness of the onedimensional approach to EO. 
Ninety-two of 119 (77.3\%) discovered EO studies based their instrument on the three constructs as proposed by Miller (1983), mainly utilising Covin and Slevin's (1989) instrument. While it becomes apparent that the three original components of EO, namely innovativeness, risk-taking and proactiveness, are extensively utilised in empirical EO research, the two additional components, autonomy and competitive aggressiveness, as proposed by Lumpkin and Dess (1996), are not as frequently included. Of the 119 studies investigating EO, only 21 (17.6\%) utilised all five constructs. Some authors have suggested that autonomy (the ability to act independently) is a natural component of risk-taking, while competitive aggressiveness (the ability to challenge competitors, both directly or indirectly, by means of new products, services or activities) can be regarded as an element of proactiveness (Basso, Fayolle \& Bouchard, 2009; Randerson \& Fayolle, 2010; Nobile \& Husson, 2016). Other constructs included items such as collaboration and experience in innovation. One study (Maritz \& Nieman, 2006) proposed differing constructs, such as opportunity-taking, urgency, performance orientation and networking. Opportunity-taking can however be viewed as an element of risk-taking, while urgency is a time-related component of proactiveness. Underlying constructs match those found by Wales, Gupta and Mousa (2011), as well as Wales (2016).

\section{Intrapreneurial Orientation}

Ten empirical studies were identified which made unique reference to investigating IO. Innovation was reflected as the only common construct across all ten studies. Other constructs included items such as risk-taking, self-esteem, achievement orientation, perceived personal control, locus of control, proactiveness, self-efficacy, the work environment, perseverance and strategic planning. Goosen, de Coning and Smit (2002) proposed an additional construct termed 'management', which included items such as goals, rewards and innovation systems, intracapital, communication, intrapreneurship championing, staff input and intrapreneurial freedom. While a number of underlying instruments were observed, three studies made use of an instrument developed by Robinson et al. (1991), while an additional three studies adapted instruments by Sayeed and Gazdar (2003) and Shetty (2004). When compared to the findings for EO, which showed a strong tendency towards three constructs, empirical IO studies showed little commonality in constructs and instruments. The limited existence of research shows that empirical IO research is still in its infancy, despite some studies dating back to 2001. This is supported by similar statements made by Sinha and Srivastaa (2013), as well as Jain and Ali (2012).

\section{Entrepreneurial Attitude Orientation}

Ten studies were discovered which investigated EAO, with 7 out of 10 studies being conducted prior to 2009, thereby indicating that EAO is not a growing phenomenon. Nine of the 10 studies adapted an instrument developed by Robinson et al. (1991), which primarily measures attitude towards entrepreneurship as a predictor of entrepreneurial activity by individual managers. The attitudinal scale is pegged at an individual level and can be regarded as an extension of Intrapreneurial Orientation (Krishnan \& Kamalanabhan, 2015). It is therefore of no surprise that similarity in underlying constructs existed. Utilised constructs included achievement orientation, innovativeness, self-esteem, and personal control. Achievement orientation is regarded as achieving results during start-up and growth of a venture. Innovativeness refers to the perceived understanding and personal goal of innovation. Self-esteem makes reference to an individual's self-belief in his/her skills. Personal control refers to an individual's perceived ability to control and influence business outcomes (Robinson et al., 1991; Qiu, 2008; Krishnan \& Kamalanabhan, 2015). Other authors suggested the addition of risk-orientation, opportunity recognition, locus of control and work environment as additional constructs (McCline, Bhat \& Baj, 2000; Jain \& Ali, 2012, 2013). Findings are supported by various other authors, such as Van Wyk and Boshoff (2004), as well as Krishnan \& Kamalanabhan (2015).

\section{Conclusion}

In ever-changing and highly competitive business environments it is of importance that mature organisations are able to adopt an entrepreneurial perspective, which weaves itself into policies, structures and decision-making style (Kotter, 2012). It is therefore of importance for organisations to be able to determine their EO/IO (Miller, 2011) and adapt where necessary. The purpose of this research was to ascertain commonly utilised constructs and antecedents of existing EO and IO instruments. This study 
therefore reviews and condenses the main underlying constructs and antecedents of existing EO and IO instruments.

Results reveal that EO receives much greater attention in empirical studies than IO. Empirical studies investigating EO primarily utilise the one-dimensional, firm-level, approach by means of investigating three constructs, namely innovativeness, risk-taking and proactiveness. The multidimensional approach as proposed by Lumpkin and Dess (1996) is much less frequently utilised in empirical EO research. Results further show that four instruments are frequently adapted for use in EO research, namely those developed by Miller and Friesen (1982), Miller (1983), Covin and Slevin (1989) as well as Lumpkin and Dess (1996). Further, the discovered EO studies displayed characteristics, by virtue of merely applying existing instruments in different contexts, as noted by Basso, Fayolle and Bouchard (2009), whereby the focus of modern EO research is primarily on operationalisation of EO, rather than conceptual coherence of constructs.

Findings for IO indicated a lack of empirical research. However, the research that was performed mainly utilised instruments developed by Robinson et al. (1991), Sayeed and Gazdar (2003) and Shetty (2004). Innovation was the only constructs shared amongst the discovered studies, with a presence of other constructs such as risk-taking, self-esteem, achievement orientation, perceived personal control, locus of control, proactiveness and self-efficacy. The wide conceptual base underlying discovered IO studies indicates a lack of understanding and insight into dominant IO constructs, and therefore present an area for future research. EAO was raised as an offspring to IO and demonstrated commonality in constructs, with Achievement orientation, Innovativeness, self-esteem, and personal control being derived from Robinson et al. (1991).

The findings provide researchers and academics with an up-to-date identification and analysis of the main constructs underlying popular EO and IO instruments. The findings allow new IO instruments to be developed according to the most frequently used and tested constructs of the EO and IO concept. This study therefore has the potential to influence future research efforts in the subject areas of EO and IO by providing a commonly utilised conceptual basis for crafting and adapting relevant data collection instruments. The findings further promote the utilisation of the IO concept and instruments, as EO is more frequently referred to when compared to IO. Findings of this study allow organisations, such as SMEs, to alter their internal entrepreneurial stance by means of targeted interventions, with the aim of promoting entrepreneurial attitudes amongst employees. This will ultimately improve financial performance and competitive standing.

Future research can include systematic reviews of the results of EO and IO studies to craft a holistic view of the outcomes of these types of studies in different contexts. Future studies could also focus on an emerging market context to determine the status quo of EO and IO research findings in developing economies. It would further be of value to investigate the evolution of the $\mathrm{EO}$ and IO concepts in terms of their underlying constructs over time. This would allow further insight into how the underlying body of knowledge has evolved over a period of time.

\section{References}

Aarakit, S.M. (2010), Intrapreneurial Orientation, Social Networks and firm performance. Unpublished Masters Dissertation. Kampala: Makerere University.

Anderson, B.S., Kreiser, K.M., Kuratko, D.F., Hornsby, J.S. \& Eshima, Y. (2015), Reconceptualizing Entrepreneurial Orientation. Strategic Management Journal, Vol.36, No.1, pp. 1579-1596.

Antoncic, B. (2007), Intrapreneurship: a comparative structural equation modeling study. Industrial Management $\mathcal{E}$ Data Systems, Vol.107, No.3, pp. 309-325.

Antoncic, B. \& Hisrich, R.D. (2003), Clarifying the Intrapreneurship concept. Journal of Small Business and Enterprise Development, Vol.10, No.1, pp. 7-24.

Antoncic, B. \& Hisrich, R.D. (2004), Corporate entrepreneurship contingencies and organizational wealth creation. Journal of Management Development, Vol.23, No.6, pp. 518-550.

Basso, O., Fayolle, A. \& Bouchard, V. (2009), Entrepreneurial Orientation, history of the formation of a concept. French Management Review (Revue française de gestion), Vol. 195, pp. 175-192.

Bolton, D.L. \& Lane, M.D. (2012), Individual entrepreneurial orientation: development of a measurement instrument. Education + Training, Vol.54, No.2/3, pp. 219-233. 
Burgers, H. \& Van Der Vrande, V. (2016), Who is the corporate entrepreneur? Insights from opportunity discovery and creation theory. In: Handbook of Research on Corporate Entrepreneurship. Cheltenham: Edward Elgar Publishing.

Covin, J.G. \& Lumpkin, G.T. (2011), Entrepreneurial Orientation Theory and Research: Reflections on a Needed Construct. Entrepreneurship Theory and Practice, Vol.35, No.5, pp. 855-872.

Covin, J.G. \& Slevin, D.P. (1989), Strategic management of small firms in hostile and benign environments. Strategic Management Journal, Vol.10, No.1, pp. 75-87.

Covin, J.G. \& Slevin, D.P. (1991), A conceptual model of entrepreneurship as firm behavior. Entrepreneurship: Theory and Practice, Vol.16, pp. 7-25.

Covin, J.G. \& Wales, W.J. (2012), The measurement of entrepreneurial orientation. Entrepreneurship Theory and Practice, Vol.36, No.4, pp. 677-702.

De Villiers-Scheepers, M.J. (2012), Antecedents of strategic corporate entrepreneurship. European Business Review, Vol.24, No.5, pp. 400-424.

Dyer, L.M. \& Ross, C.A. (2008), Seeking advice in dynamic and complex business environment: Impact on the success of small firms. Journal of Development Entrepreneurship, Vol.13, No.2, pp. 133-149.

Farsi, J.Y. \& Toghraee, M.T. (2014), Identification the main challenges of small and medium sized enterprises in exploiting of innovative opportunities (Case study: Iran SMEs). Journal of Global Entrepreneurship Research, Vol.4, No.4, pp. 1-15.

Fasnacht, D. (2009), Open Innovation in the Financial Services: Growing Through Openness, Flexibility and Customer Integration. Berlin: Springer-Verlag.

Filser, M. \& Eggers, F. (2014), Entrepreneurial orientation and firm performance: A comparative study of Austria, Liechtenstein and Switzerland. Southern African Journal of Business Management, Vol.45, No.1, pp. 55-65.

Guth, W.D. \& Ginsberg, A. (1990), Guest editors' introduction: Corporate entrepreneurship. Strategic Management Journal, Vol.11, No.1, pp. 5-15.

Heinonen, J. (1999), Towards Customer Orientation and Competitiveness. The Potential of Intrapreneurship in the Change Process of a Municipal Service Unit. Publications of the Turku School of Economics and Business Administration, Series A-5.

Hisrich, R.D. \& Peters, M.P. (2002), Entrepreneurship. Boston: McGraw- Hill/Irwin.

Hughes, M., Ucbasaran, D. \& Lewis, M. (2016), A dynamic human capital perspective on corporate opportunity identification. In: Handbook of Research on Corporate Entrepreneurship. Cheltenham: Edward Elgar Publishing.

Hunter, J.E. \& Schmidt, F.L. (2004), Methods of Meta-Analysis: Correcting Error and Bias in Research Findings. Thousand Oaks: Sage Publishing.

Jacobs, H. \& Kruger, S. (2001), Establishing an intrapreneurial orientation as strategy: A framework for implementation. Acta Commercii, Vol.1, No.1, pp. 1-11.

Jain, R. \& Ali, S.W. (2012), Entrepreneurial and Intrapreneurial Orientation in Indian Enterprises: An Empirical Study. South Asian Journal of Management, Vol.19, No.3, pp. 86-122.

Junior, A.E.D., Borini, F.M., Bernardes, R.C. \& de Oliveira, M.J. (2016), Impact of Entrepreneurial Orientation on Strategic Alliances and the Role of Top Management. Journal of Business Management (Revista de Administração de Empresas), Vol.56, No.3, pp. 315-329.

Kantur, D. (2016), Strategic entrepreneurship: mediating the entrepreneurial orientation performance-link. Management Decision, Vol.54, No.1, pp.24-43.

Khandwalla, P.N. (1977), The Design of Organizations. New York, NY: Harcourt Brace Jovanovich.

Kotter, J.P. (2012), Accelerate. Harvard Business Review, Vol. 90, No.11, pp. 43-58.

Krishnan, L. \& Kamalanabhan, T.J. (2015), Entrepreneurial Success and Life Satisfaction Among Women Entrepreneurs in Micro Enterprises. South Asian Journal of Management, Vol. 20, No. 2, pp. 40-63.

Kuratko, D.F. (2017), Entrepreneurship: Theory, Process, Practice. Boston: Cengage Learning.

Lumpkin, G.T. \& Dess, G.G. (1996), Clarifying the entrepreneurial orientation construct and linking it to performance. Academy of Management Review, Vol.21, No.1, pp.135-172.

Lumpkin, G.T. \& Dess, G.G. (2005), The role of entrepreneurial orientation in stimulating effective corporate entrepreneurship. The Academy of Management Executive, Vol.19, No.1, pp. 147-156.

Macrae, N. (1982), Intrapreneurial now. The Economist. Available from: www.entrepreneurs.about.com/cs/intrapreneurship.html (Accessed 20 July 2017)

Manimala, M.J., Jose, P.D. \& Thomas, K.R. (2006), Organizational Constraints on Innovation and Intrapreneurship: Insights from Public Sector. Vikalpa, Vol.31, No.1, pp. 49-60.

Matchaba-Hove, T.M. \& Goliath, J.E. (2016), The entrepreneurial orientation and business performance relationship: a study of young adult-owned small businesses. Proceedings of the $28^{\text {th }}$ Annual Conference of the Southern African Institute of Management Scientist, held in Pretoria, South Africa. 
McCline, R.L., Bhat, S. \& Baj, P. (2000), Opportunity Recognition: An Exploratory Investigation of a Component of the Entrepreneurial Process in the Context of the Health Care Industry, Entrepreneurial Theory and Practice, Winter, pp. 81-94.

Milat, A.J., Bauman, A.E. \& Redman, S. (2015), A narrative review of research impact assessment models and methods. Health Research Policy and Systems, Vol.13, No.18, pp. 1-6.

Miller, D. (1983), The correlates of entrepreneurship in three types of firms. Management Science, Vol.29, No.7, pp. 770791.

Miller, D. (2011), A reflection on EO research and some suggestions for the future. Entrepreneurship Theory and Practice, Vol.35, No.5, pp. 873-894.

Nobile, D. \& Husson, J. (2016), Entrepreneurial orientation in local authorities: A case study of the health care network in Lorraine. International Journal of Technology Management E Sustainable Development, Vol.15, No.2, pp. 177-190.

Pinchot, G. (1985), Intrapreneuring. New York: Harper \& Row.

Randerson, K. \& Fayolle, A. (2010), Entrepreneurial Management and Entrepreneurial Orientation: Are these Two Concepts so different? Management \& Avenir, Vol.39, pp. 124-135.

Rauch, A., Wiklund, J., Lumpkin, G.T. \& Frese, M. (2009), Entrepreneurial orientation and business performance: an assessment of past research and suggestions for the future. Entrepreneurship Theory and Practice, Vol.33, No.3, pp. 761-787.

Robinson, P.B., Stimpson, D.V., Huefner, J.C. \& Hunt, H.K. (1991), An attitude approach to the prediction of entrepreneurship. Entrepreneurship Theory \& Practice, Vol.15, No.4, pp. 13-31.

Sinha, N. \& Srivastava, K.B.L. (2013), Association of Personality, Work Values and Socio-cultural Factors with Intrapreneurial Orientation. The Journal of Entrepreneurship, Vol.22, No.1, pp. 97-113.

Taştan, S.B. \& Güçel, C. (2014), Explaining Intrapreneurial Behaviors of Employees with Perceived Organizational Climate and Testing the Mediating Role of Organizational Identification: A Research Study among Employees of Turkish Innovative Firms. Procedia - Social and Behavioral Sciences Vol.150, pp. 862-871.

Van Aardt, I. \& Bezuidenhout, S. (2017), Entrepreneurship \& New Venture Management. Cape Town: Oxford University Press.

Van Wyk, R. \& Boshoff, A.B. (2004), Entrepreneurial attitudes: A distinction between two professional groups. South African Journal of Business Management, Vol. 35, No.2, pp. 33-38.

Wales, W.J. (2016). Entrepreneurial Orientation: A review and synthesis of promising research directions. International Small Business Journal, Vol. 34, No.1, pp. 3-15.Wales, W.J., Gupta, V.K. \& Mousa, F.T. (2011), Empirical research on entrepreneurial orientation: an assessment and suggestions for future research. International Small Business Journal, Vol. 31, No.4, pp. 357-383.

Wang, C.L. \& Altinay, L. (2010), Social embeddedness, entrepreneurial orientation and firm growth in ethnic minority small businesses in the UK. International Small Business Journal, Vol. 30, pp. 3-23.

Wiklund, J. (1999), The sustainability of the entrepreneurial orientation-performance relationship. Entrepreneurship Theory and Practice, Vol.(Fall), pp. 37-48.

Wiklund, J. \& Shepherd, D. (2005), Entrepreneurial orientation and small business performance: a configurational approach. Journal of Business Venturing. Vol.20, No.1, pp.71-89.

Wunderer, R. (2001), Employees as "co-intrapreneurs" - a transformation concept. Leadership E Organization Development Journal, Vol.22, No.5, pp. 193-211. 